\title{
To med(iastinoscopy) or not to med(iastinoscopy)
}

\author{
Joanna Sesti, MD, ${ }^{\mathrm{a}, \mathrm{b}}$ and Subroto Paul, MD, MPH ${ }^{\mathrm{a}, \mathrm{b}}$
}

\author{
From the Departments of a Surgery, and the ${ }^{\mathrm{b}}$ Cardiothoracic Surgery, Saint Barnabas Medical Center, Newark \\ Beth Israel Hospital, RWJBarnabas Health, Livingston, NJ. \\ Disclosures: Authors have nothing to disclose with regard to commercial support. \\ Received for publication Jan 4, 2018; accepted for publication Jan 12, 2018; available ahead of print Feb 15, 2018. \\ Address for reprints: Subroto Paul, MD, MPH, Department of Cardiothoracic Surgery, RWJBarnabas Health, 94 \\ Old Short Hills Rd, Suite 1172, Livingston, NJ 07039 (E-mail: Subroto.Paul@rwjbh.org). \\ J Thorac Cardiovasc Surg 2018;155:2672-3 \\ $0022-5223 / \$ 36.00$ \\ Copyright (c) 2018 by The American Association for Thoracic Surgery \\ https://doi.org/10.1016/j.jtcvs.2018.01.039
}

Variation in health care delivery is not a new concept. Wennberg and Gittelsohn's seminal work ${ }^{1}$ examining the disparities in the use of health care services in Vermont laid the foundation for much of health services research more than 40 years ago. ${ }^{1}$ Variations in use of a particular service indicate a level of uncertainty; uncertainty in either the effectiveness of the particular service, the need to perform a service, or the quality of the service provided.

In this issue of the Journal, Thornblade and colleagues ${ }^{2}$ provide yet another example. Invasive mediastinal staging by mediastinoscopy, endobronchial ultrasonography, or endoscopy ultrasonography is known to be underutilized. $^{3-10}$ The work of Thornblade and colleagues ${ }^{2}$ demonstrates variability in the use of invasive mediastinal staging that cannot be explained by patient or other clinical factors. Much like the work of Wennberg and Gittelsohn ${ }^{1}$ in Vermont, variability exists within a geographically restricted area of Puget Sound, Wash.

What does this mean, and why do we care? The variation in the use of mediastinal staging could suggest that the evidence supporting its use is weak, and its effectiveness thus is disputable in the minds of many providers. Alternatively, it could mean that knowledge gaps regarding the most current guidelines exist for many providers, leading to suboptimal lung cancer staging. Either suggests that there is a quality gap in the processes of care delivery warranting either further investigation or provider education.

The potential for less than optimal patient care should in and of itself be enough for us to care. Other stakeholders, however, are starting to look at variation in health care. Unwarranted tests not only can lead to harm but also can be expensive. The Choosing Wisely campaign by the American Board of Internal Medicine and other specialties is an attempt to reduce variability by discouraging the use of ineffective tests. The Leapfrog Group, a national nonprofit organization that surveys hospitals for quality and popularized minimum volume thresholds for procedures such as esophagectomies, dard of care.

\section{References} 1973;182:1102-8. 155:2658-71.e1. 2051-6.

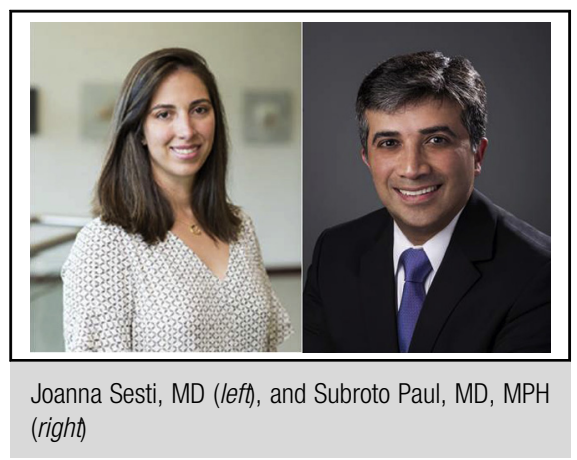

Central Message

Variation in the use of mediastinal staging suggests that the evidence supporting its use is weak or that gaps in knowledge exist, leading to suboptimal lung cancer staging.

See Article page 2658.

now has a 2018 initiative examining the appropriateness of procedures, including lung and esophageal resection. Although not well defined, this is a first dive into reducing variability. For example, one could ask whether invasive mediastinal staging was done for fludeoxyglucose-avid nodes on a positron emission tomographic computed tomographic scan. Insurers may in the future not pay providers if they fail to adhere to the stan-

Thornblade and colleagues ${ }^{2}$ are to be commended on their work. Their findings challenge us to examine whether their findings are widespread, if so to ask why, and then to remedy the situation. Otherwise, someone else will.

1. Wennberg J, Gittelsohn. Small area variations in health care delivery. Science.

2. Thornblade LW, Wood DE, Mulligan MS, Farivar AS, Hubka M, Costas KE, et al. Variability in invasive mediastinal staging for lung cancer: a multicenter regional study. J Thorac Cardiovasc Surg. 2018;

3. Little AG, Rusch VW, Bonner JA, Gaspar LE, Green MR, Webb WR, et al. Patterns of surgical care of lung cancer patients. Ann Thorac Surg. 2005;80:

4. Little AG, Gay EG, Gaspar LE, Stewart AK. National survey of non-small cell lung cancer in the United States: epidemiology, pathology and patterns of care. Lung Cancer. 2007;57:253-60.

5. Farjah F, Flum DR, Ramsey SD, Heagerty PJ, Symons RG, Wood DE. Multi-modality mediastinal staging for lung cancer among Medicare beneficiaries. $J$ Thorac Oncol. 2009; 4:355-63.

6. Lathan CS, Neville BA, Earle CC. The effect of race on invasive staging and surgery in non-small cell lung cancer. J Clin Oncol. 2006;24:413-8. 
7. Vest MT, Tanoue L, Soulos PR, Kim AW, Detterbeck F, Morgensztern D, et al. Thoroughness of mediastinal staging in stage IIIA non-small cell lung cancer. J Thorac Oncol. 2012;7:188-95.

8. Ost DE, Niu J, Elting LS, Buchholz TA, Giordano SH. Determinants of practice patterns and quality gaps in lung cancer staging and diagnosis. Chest. 2014;145: 1097-113.
9. Ost DE, Niu J, Elting LS, Buchholz TA, Giordano SH. Quality gaps and comparative effectiveness in lung cancer staging and diagnosis. Chest. 2014 145:331-45.

10. Faris N, Yu X, Sareen S, Signore RS, McHugh LM, Roark K, et al. Preoperative evaluation of lung cancer in a community health care setting. Ann Thorac Surg. 2015;100:394-400. 